\title{
Russian and Buryat ethno-cultural interaction in the 17th-19th centuries
}

DOI: $10.31551 / 2410-2725-2018-4-2-215-233$

\section{Burayeva Olga Vladimirovna}

Doctor of History, Assist.professor, Chief researcher of The Institute for Mongolian, Buddhist and Tibetan Studies of the Siberian Branch of the Russian Academy of Sciences. Russia, 670047, Ulan-Ude, Sakhjyanova St., 6. E-mail: olgaburaeva@mail.ru

Abstract. The appeal to the history of contacts of the Russian culture with the cultures of other people is of interest because this material gives a variety of options of contacts and the loans arising at the same time. The Baikal region is of special interest. In the course of migrations in very extensive territory Russians have contacted with representatives of the most different cultures, including Buryats that has found reflection both in material, and in spiritual cultures of both ethnoses.

Key words: Baikal region; Russians; Buryats; interethnic interaction; material culture; spiritual culture.

\section{XVII-XIX fF. орыс-бурят этномәдени өзара әсерлесуі}

\section{Бураева Ольга Владимировна}

тарих ғылымдарының докторы, доцент, РҒА СБ моңғолтану, буддология және тибетология Институтының жетекші ғылыми қызметкері. 670047, Улан-Удэ қ, ул. Сахьянова к, 6 үй. E-mail: olgaburaeva@mail.ru

Аңдатпа. Ресей мәдениеті мен басқа ұлттар мәдениеттері арасындағы байланыс тарихын қарастыру қызығушылық тудырады, өйткені бұл материал байланыстар мен алынған әсерлесулердің түрлі нұсқаларын ұсынады. Байкал аймағы ерекше қызығушылық тудырады. Өте үлкен аумақтағы көші-қон үрдісінде орыстар әртүрлі мәдениеттердің өкілдерімен, соның ішінде буряттармен байланыс орнатқандығы этникалық топтардың материалында да, рухани мәдениетінде де көрініс тапты.

Кілт сөздер: Байкал аймағы; орыстар; буряттар; этникаарлық өзара әсерлесу; материалды мәдениет; рухани мәдениет.

\section{Русско-бурятское этнокультурное взаимодействие в XVII-XIX вB.}

\section{Бураева Ольга Владимировна}

доктор исторических наук, доцент, ведущий научный сотрудник, Институт монголоведения, буддологии и тибетологии СО РАН. 670047, г. Улан-Удэ, ул. Сахьяновой, 6, ИМБТ СО РАН. Е-mail: olgaburaeva@mail.ru.

Аннотация: Обращение к истории контактов русской культуры с культурами других народов представляет интерес потому, что этот материал дает разнообразие вариантов контактов и возникающих при этом заимствований. Особый интерес представляет Байкальский регион. В процессе миграций на весьма обширной территории русские вошли в контакт с представителями самых разных культур, в том числе бурятами, что нашло отражение как в материальной, так и в духовной культурах обоих этносов.

Ключевые слова: Байкальский регион; русские; буряты; межэтническое взаимодействие; материальная культура; духовная культура.

\section{ӘОЖ/ УДК 94(47+57)}

\section{Русско-бурятское этнокультурное взаимодействие в XVII-XIX вв. ${ }^{1}$}

\section{O.В. Бураева}

Введение. Общий ход этнической истории народов Байкальского региона во втором тысячелетии был определен двумя основными этнополитическими событиями, сыгравшими важнейшую роль в судьбе населения Евразии. Это

\footnotetext{
${ }^{1}$ Работа выполнена в рамках государственного задания Федерального государственного бюджетного учреждения науки «Институт монголоведения, буддологии и тибетологии Сибирского отделения Российской академии наук (ИМБТ СО РАН)» по проекту XII.191.1.1. «Трансграничье России, Монголии и Китая: история, культура, современное общество», номер госрегистрации № АААА-А17-117021310269-9.
} 
возникновение, подъем и развитие монгольского и русского этносов, создавших на протяжении одного тысячелетия две великие державы, в состав которых входили и земли, прилегающие к Байкалу. Монголы и империя Чингисхана открыли эпоху развитого средневековья, русские и Российское государство эпоху нового времени. Включение Сибири в состав молодого русского государства не просто вывело ее народы на новый виток развития, но и кардинально изменило весь ход их дальнейшего развития. Оно не только обеспечило этим народам поступательное движение в общем процессе социально-экономического и технологического развития Старого Света, но и вовлекло их в единое культурное пространство Евразии, способствуя более активному участию сибирских этносов в жизни мировой цивилизации. В рамках этих двух направляющих в XVII - XIX вв. на территории Предбайкалья и Забайкалья развернулись и интенсивные этногенетические процессы, в результате которых возникли новые народы, составляющие современную этническую картину региона (Павлинская 1999: 165).

История культурного взаимодействия русского и бурятского этносов насчитывает более трех веков. Освоение Байкальской Азии началось сразу вслед за ее присоединением к России в середине XVII в. В процессе миграции русские вошли здесь в контакт с представителями самых разных культур - бурятами, эвенками, тофаларами, сойотами и др.

Активная адаптация к новым условиям сопровождалась у русских перестройкой традиционного образа жизни, появлением новаций, в том числе и заимствованных в культуре местных народов.

Природные климатические факторы оказали влияние, прежде всего, на культуру жизнеобеспечения: хозяйственную деятельность, жилище, пищу, одежду. Наиболее чутко реагировала на изменения природных условий производственная деятельность этносов. Сложившиеся в XVII в. предпосылки для развития культурного диалога реализовались в достаточно интенсивные культурные связи в последней трети XIX в.

Присоединение и заселение. Присоединение народов, населяющих юг Восточной Сибири, происходило на протяжении 20-70-х гг. XVII в. И хотя завоевание было совершено небольшими силами, сам процесс покорения не был кратковременным и легким. Приведенные к покорности и обложенные ясаком буряты неоднократно восставали. Однако усиление маньчжуро-китайской экспансии не могло не сказаться на характере присоединения к России покоренных народов. К концу 50-х - началу 60-х гг. XVII в. у них проявилось стремление к закреплению в составе России.

Сразу за присоединением началось заселение завоеванных территорий. Русское население сначала концентрировалось вокруг основанных острогов, которые являлись центрами сбора ясака, охраны границ и транспортных путей. Вокруг них стали расти деревни, заимки, слободы, которые появлялись по берегам рек по мере продвижения русских на юг и восток от Байкала. В результате этого уже в XVII в. существенно изменилась этнографическая карта края. Русские деревни перемежались с бурятскими улусами и эвенкийскими стойбищами, вследствие чего началось взаимодействие этносов.

Перед нами тот вариант контакта двух разностадиальных обществ, когда экзогенный фактор оказал благоприятное воздействие на ход этнических и культурных процессов благодаря стечению сразу нескольких обстоятельств.

Прежде всего, это характер самой культуры скотоводческого общества, которой свойственна высокая степень мобильности, как в прямом, так и переносном смысле. Динамический способ ведения хозяйства: постоянные перекочев- 
ки, осваивание все новых территорий, высокая степень его технологичности и открытости инновациям, рождающие психологическую адаптивность и вместе с тем способность сохранять культурную традицию - все это способствовало естественному и быстрому вступлению скотоводов в разные виды этнокультурных контактов и установлению прочных симбиотических связей с обществами иных хозяйственно-культурных типов. Важным моментом стало то, что буряты занимали территории, являющиеся мостом между двумя очагами цивилизаций Запада и Востока, которые исторически были предназначены к роли важнейшей контактной зоны.

В немалой степени этому способствовал и древний исторический опыт славянской земледельческой культуры русских, которая уже с первых этапов своего существования всегда активно взаимодействовала с кочевыми скотоводческими культурами евразийских степей. И в данном случае сработала культурно-генетическая память русского этноса.

Отражение взаимодействия в хозяйстве. С каждым десятилетием бурятский улус все больше включались в общую хозяйственную жизнь Восточной Сибири. Это так же, как и налоговая политика государства (с 1762 г. натуральная подать хлебом и ясаком заменена денежной), подрывало натуральные устои скотоводческого хозяйства. Потребность в деньгах побуждала развивать те отрасли, которые давали возможность получать товарную, легко реализуемую на местном рынке продукцию. Такой отраслью было, прежде всего, земледелие.

Рост колонизации, развитие внешней и внутренней торговли, зарождение промышленных предприятий, увеличение населения в городах и на заводах, необходимость продовольствия для ссыльнокаторжных и воинских частей все это повышало спрос на продукты сельского хозяйства. Первоначальное существование двух хозяйственно-культурных типов со второй половины XVIII в. сменяется активным вовлечением бурятского населения в земледельческое хозяйство. Этому способствовал и ряд государственных указов, обеспечивающих для бурят режим наибольшего благоприятствования в этой деятельности. Занятие земледелием требовало от бурят овладения новыми технологиями, что в исторической перспективе означало для бурятской культуры быстрое преодоление стадиальной дистанции. При этом скотоводство оставалось для бурят основным видом хозяйствования.

Судя по архивным данным, пионерами земледелия были родовые начальники, к чему их всемерно побуждали власти. У имущих слоев было больше возможностей в приобретении сельскохозяйственного инвентаря, семян. Но росла запашка и в неимущих хозяйствах, уже неспособных прокормиться за счет одного скотоводства. Потребность же в деньгах, в которых нуждались все социальные группы общества, способствовала развитию новой отрасли хозяйства.

Система земледелия и орудия у бурят были такими же, как у русских. Приемы земледелия бурятское население воспринимало от окружающего русского крестьянства и своих сородичей, приступивших к нему ранее. Широкое распространение получили в первой половине хлебозапасные магазины.

Способы ведения хозяйства и орудия труда не претерпели серьезных изменений и продолжали оставаться во второй половине XIX в. примитивными: деревянная соха-рогалюха, соха-колесуха, сабан, плуг, борона. В конце XIX в. стали распространяться веялки, молотилки, сеялки, но они не получили широкого распространения до проведения Транссибирской железной дороги. 
Буряты применяли свою технологию облагораживания почвы, которая сводилась к обильному удобрению полей навозом и искусственному орошению. С экономической точки зрения, такая агротехника была прогрессивной, опережавшей свое время.

В разной степени в Иркутской губернии было развито огородничество. Как русские, так и буряты разводили капусту, табак, коноплю, огурцы, морковь, свеклу, редьку, горчицу, горох, арбузы, дыни, лук, чеснок, помидоры, тыкву, брюкву.

Бурятское население, перенимая и постепенно усваивая от русских земледельческие приемы и навыки земледельческого хозяйства, приобретали у них не только орудия, но и зерно. Поэтому в бурятском языке можно встретить целый ряд русских слов, обозначающих хлебные и другие растения, сельскохозяйственные орудия и другие слова, относящиеся к хозяйству: яровая рожь яарса, ячмень - яшмен, ешмээн, ярица - яарса, пшеница - шениисэ, гречиха гэршууха, просо - поросс, пороссо, овес - обеос, мякина - мехина, овин обин, борона - борной, колесуха - колесууха, волокуша - булхаа, межа - муужа, сусек - шушээг, борозда - бураздаа, серп - сеэрпэ, шээрпэ, соха - сохаа. Предположительно, эти слова вошли в бурятский язык в конце XVII - начале XVIII в. Бурятские термины сельскохозяйственных орудий, возможно, монгольского происхождения.

Скотоводство в крае находилось исключительно в руках местных бурят и их соседей монголов, которые снабжали русское население как молочным, так и мясным скотом. Приемы и способы ведения скотоводческого хозяйства в Иркутской губернии и Забайкальской области не были одинаковыми. Они различались у бурятского и русского населения.

Еще в XVII в. отдельные бурятские роды заготавливали сено, но в небольших размерах. О бытовании сенокошения у бурят до прихода русских говорит и бурятская терминология, связанная с этим видом деятельности. Более широко сенокошение начинает практиковаться в XVIII в. В конце XVIII - первой половине XIX в. в скотоводческом хозяйстве бурят происходят качественные изменения, связанные с ограничением перекочевок и развитием сенокошения.

Характерно, что сенокошение быстрее развивалось у западных бурят, которые были менее обеспечены скотом, так как падеж скота на их хозяйстве сказывался более сильно, и восстановить его поголовье было труднее. В Забайкалье преобладало пастбищное скотоводство на подножном корму, но и здесь увеличивалась заготовка сена для подкормки скота зимой.

Несомненным достижением бурят следует считать удобрение и орошение ими своих сенокосов. Удобренные сенокосы у бурят назывались утугами. Во многих районах они еще и орошались, наряду с обычными неудобренными сенокосными угодьями. Утужная система значительно повышала урожайность естественных сенокосов, улучшала состав травостоя и качество сена.

Унавоживание лугов в русских селах было новым явлением. И было заимствовано у бурят не раньше 1870-1880-х гг. Характерно, что утуги существовали в тех русских селениях, которые были расположены вблизи бурятских улусов.

Многие русские крестьяне скотоводческих районов вели свои хозяйства по типу бурят. Содержание скота здесь было чисто бурятским.

Старожилое русское население многое почерпнуло из богатой скотоводческой практики бурят в новых для русского крестьянства условиях. Русские приобретали скот местной породы и усваивали различные навыки ведения скотоводческого хозяйства в местных условиях. Некоторые нерчинские казаки, осо- 
бенно из числа богачей, обзаведясь огромными стадами скота, даже перешли к кочевому образу жизни, тогда как буряты уже начинали его оставлять.

Бывшие хлебопашцы, превратившись в скотоводов, мало чем отличались в быту от бурят. Приспосабливаясь к новым условиям жизни, русские перенимали у бурят вместе с самими понятиями названия из области скотоводства. Род занятий заставлял заимствовать дифференцированную скотоводческую лексику бурят, названия животных по отношению к ним как к производителям, слова, определяющие признаки домашних животных, названия лошадей по масти. Подражая бурятам, русские приучали, по всем правилам бурятского наезднического искусства, диких степных лошадей резко останавливаться и стоять без привязи на одном месте. Они также заимствовали все принадлежности седлания лошадей вместе с бурятскими названиями.

Буряты под влиянием русских узнали способы изготовления телег и саней. А с 1810 г. научились изготовлять конскую сбрую, хомут, дугу, вожжи, седелки, чересседельник и поводья. Они стали при их помощи запрягать лошадей в телеги и сани и активно участвовать в грузоперевозках и почтово-курьерской службе. И если упряжь верховой езды, как в западном, так и восточном наречиях бурят не имеет заимствований, то большинство названий тягловой упряжи взято из русского языка (хомууд, божжо, гужэ, супоон, шодолха и др.).

Русское влияние сказалось на разложении натурального хозяйства бурятского населения, на развитии товарно-денежных отношений. Оно повысило культуру основной отрасли бурятского хозяйства - животноводства. В этой области влияние было обоюдным.

У бурят произошли значительные изменения под влиянием русских. Вопервых, ослабла зависимость от произвола стихии. Широкое распространение сенокошения вследствие ограничения кочевок, переход к стойловому содержанию скота уменьшили зависимость хозяйства от природных условий. При сенокошении пользовались привозными из европейской части России косами, совершенствуя их. Русские крестьяне со временем тоже стали пользоваться поливными лугами.

Русское население смогло адаптироваться к сибирским условиям, используя внутренние резервы и опыт автохтонного населения, заимствуя у них необходимые элементы. Заимствования в добыче копытных были обусловлены природным фрактором. Процесс заимствования у бурят прекрасно иллюстрируется русской промысловой лексикой. Процесс адаптации в рыболовстве и промысле на нерпу у русских происходил путем изменения традиционных форм, но во взаимодействии с промысловыми приемами и знаниями бурят. От бурят была воспринята постройка охотничьей юрты. Буряты стали активнее применять огнестрельное оружие во время охоты, появились ловушки (пасти, кулемы).

Собирательство было широко распространено у коренных народов региона. Русские познакомились с новой фрлорой и заготавливали черемшу, сарану, мангир, ранее им неизвестные.

Процесс взаимодействия в ремесленной области не означал обязательных заимствований. Оно проявлялось, скорее всего, в обмене услугами. Так, русские предпочитали отдавать бурятам шкуры и шерсть для обработки, считая их искусными мастерами в этом деле, приобретали ювелирные изделия бурятских кузнецов, предпочитали пользоваться услугами бурятских бондарей.

Русское влияние на бурятские промыслы сказалось незначительно. Скорее даже некоторые промыслы пришли в упадок. В то же время у бурят появились 
плотники, которые делали сани, телеги, сохи и другие сельскохозяйственные орудия, строили дома.

Торговля с древнейших времен была и остается одной из форм межэтнического общения. С приходом русских в Сибирь торговые отношения бурят расширились и видоизменились. Натуральный характер хозяйства обусловливал слабое развитие внутренней торговли. Торговля носила разъездной характер. В конце 60-х гг. XVIII в. на границе с Монголией была открыта постоянная точка для торговли. Кяхтинская торговля оказала ощутимое влияние на хозяйственное развитие региона. Сотрудничество торговой деятельности явилось стимулом для общего развития этнических культур, открывая новые пути для проникновения в нее различных инноваций.

Изменения в образе жизни бурят. Уже с начала XVIII в. наметились изменения в образе жизни бурят. Развитие земледелия и сенокошения у бурят имело большое значение для перехода их к оседлости, что привело к строительству домов русского типа.

По мере освоения обширных земель русским населением, роста числа городов и населенных пунктов, развития промышленных предприятий и распространения хлебопашества буряты начали селиться компактнее, образуя нередко значительные улусы. В их жизни все большее значение приобретали города, крупные села как экономические центры, в которых сосредоточивались производственные, административные, торговые и культурные учреждения. Наметился переход бурят на полукочевой, а отчасти и на оседлый образ жизни. Однако в разных районах Бурятии характер поселений и фрормы жилищ были своеобразными, что объясняется природно-климатическими условиями и особенностями социально-экономического развития.

Переход к занятию земледелием не мог не сказаться на образе жизни бурят. Среди них развивались различные переходные фрормы от кочевья к оседлости. Этот процесс сказывался и в домашнем быту. Войлочные юрты стали вытесняться деревянными, строили теплые зимовья. Развивалось строительство домов русского типа.

Разумеется, с ростом народонаселения увеличивалось число жилищ. Причем это увеличение было качественным, т.е. наряду с ростом количества юрт стало больше рубленых домов.

Русское влияние не было равномерным: оно сильнее сказывалось в тех местностях, где буряты ближе соприкасались с русскими, и слабее там, где это соприкосновение было сравнительно менее близким. Так, русское влияние среди балаганских бурят было заметнее, чем среди тункинцев. В Тункинском ведомстве влияние заметнее всего сказывалось в тех местах, где бурятские улусы чаще перемежались с селениями русских крестьян и казаков. Такое же явление происходило и в Забайкальской области.

B начале $\mathrm{XX}$ в. бурятские поселения Западного Забайкалья имели вид маленьких деревушек, разбросанных по речным долинам и нагорьям. Основным типом жилища здесь еще в XIX в. стал бревенчатый дом, родственный русским срубным жилищам. Принцип и техника были заимствованы у местных русских крестьян. Первые дома в хотонах были построены с помощью русских плотников. Однако в конце XIX - начале XX в. наряду со срубными избами бытовало традиционное жилище - войлочная юрта. В юртах жили преимущественно на летних пастбищах, но в некоторых улусах много юрт оставалось в хотонах (у 
семей, не вышедших в летники). Летом из деревянных домов они переходили в юрты, которые стояли во дворе.

C начала $\mathrm{XX}$ в. в Западном Забайкалье в связи с развитием товарного земледелия и сенокошения, с усилением экономических связей с городом, началось интенсивное строительство жилых домов. Богатые и зажиточные буряты строили срубные дома, бедные же оставались в ветхих избушках, называемых земье (искаженное от рус. зимовье). В этот период войлочные юрты окончательно вытесняются деревянными жилищами. Даже на летних пастбищах вместо войлочных юрт стали строить небольшие четырехстенные срубы с низкими крышами и без окон.

Новым в расселении и жилищах у бурят явились заимки, возникшие в первую очередь у зажиточных. Они строились около покосов и пашен. Иногда туда на зиму перегонялся скот, так как сено с отдаленных покосов не возили в зимники, а складывали на заимках. Заимки были индивидуальные и групповые.

В улусах появились лавки, погреба, хлебозапасные магазины или склады, школы, здания управ, ведомств, церкви и миссионерские станы, а в конце XIX в. - пожарные сараи.

В начале XX в. войлочные юрты слегка модернизировали: часть верхнего отверстия юрты закрывали остекленной рамой, так как вместо очага стали топить маленькие печки из плиточного камня, которые вскоре научились делать из кирпича, пользовались и железными печками. На юго-западной стороне юрты рядом с дверью стали прорезать небольшие оконца. А появление в бурятском языке русских названий, связанных с внутренним устройством дома, говорит об укоренении этих реалий в быту.

Переход к жизни в жилище оседлого типа у бурят осуществлялся постепенно, причем на первых этапах отмечались оба типа. Заимствование у оседлого русского населения конструкции, техники постройки, планировки и отделки жилья - явление довольно распространенное. В дальнейшем жилища традиционного типа начинают использоваться сезонно (летом) как хозяйственные помещения. Рядом с чумом или войлочной юртой повсеместно вырастает четырехстенная изба.

Этнические традиции проявлялись главным образом в интерьере, однако и здесь к началу XX в. произошли существенные изменения. Культурные взаимовлияния сказались в планировке и функциональном использовании помещений. В сельской местности получает распространение жилище с планировкой городского типа. Намечаются тенденции увеличения камерности с функциональным обособлением необходимых помещений (кухни, спален).

Несомненно, проводниками русской культуры была верхушка бурятского общества. Именно родовые начальники строили русские дома, приобретали русскую мебель и утварь, одежду, продукты питания, а уже через них все попадало в бурятское общество.

Изменения в системе питания русских и бурят. В результате культурных контактов народов происходит взаимное обогащение пищевых рационов. Если структура пищи контактирующих народов различна, заимствование развивается в обе стороны, по линии преобладающих компонентов. Русские, где бы они ни поселялись, обогащали рацион народов, с которыми соприкасались, главным образом хлебными изделиями и блюдами растительного происхождения, сами же с легкостью усваивали местные блюда из рыбы и мяса. 
Русские, переселившиеся в Сибирь, в основном сохранили свою традиционную мучную пищу, однако в тех районах, где преобладали промыслы, пища их под влиянием географической среды и окружающего населения включала новые компоненты.

На первоначальном этапе освоения Сибири большую роль играли новшества, связанные с включением в рацион переселенцев продуктов местной фолоры и фауны (дикий лук - мангир, черемша, дикий чеснок, сарана и др., мясо диких животных и птиц). Лук, сарану, кипрей заготавливали на зиму, засаливая или засушивая. Продукты охоты и рыболовства были первостепенными в питании. В пищу употребляли медвежатину, оленину, зайчатину, куропаток, гусей, различную рыбу (щук, карасей, осетров, стерлядь).

У местного населения были заимствованы способы приготовления и хранения пищи, в частности сушение, или вяление, и квашение рыбы. От местного населения были восприняты основные способы заготовки сушеной рыбы и ее названия.

По примеру бурят русские приготовляли секшу, т.е. варили кровь животного и, смешивая кровяной сгусток с жиром, ели с таким же удовольствием, как и буряты. Сибиряки познакомились с чаем уже в XVIII в., который позднее стал одним из самых распространенных напитков в России. В Забайкалье из кирпичного чая варили очень питательный чай - затуран. Пшеничную муку прожаривали на вытопленном внутреннем жире-сырце баранины или говядины, затем добавляли молоко и процеженную заварку зеленого кирпичного чая, доводили до кипения, и чай готов. Любители пили слегка подсоленным. Этот способ приготовления чая явно заимствован у бурят, как и само слово затуран (бур. зутараан).

Русское население употребляло тарасун. Подобно бурятам, русские «сидели арака» - делали вино, только не из кобыльего, а из коровьего молока, но по все правилам бурятского винокурения и со всеми бурятскими принадлежностями или орудиями этого процесса, опять с усвоением и всех бурятских названий, относящихся к этому делу предметов. К выпивке молочного вина в западных районах применялись выражения «архидачить» или «духорянить», связанные с обрядом вежливости - духорян, соблюдавшимся западными бурятами в обязательном порядке. Слово «архидачить» значило пить архи (молочную водку) (или тарасун - перегнанную вторично молочную водку). Обычно во время приготовления тарасуна в юрте собирались гости и соседи, которые располагались вокруг очага. Хозяйка подавала чашку с тарасуном самому почетному или старейшему из гостей (или шаману), который сначала угощал очаг, потом отпив немного, передавал её хозяину или кому-нибудь из гостей с благопожеланиями. Получивший отпивал тарасун, отвечая на приветствие, доливал в чашку тарасун и снова передавал её подавшему, который на этот раз выпивал до дна. Так происходило с каждым присутствующим. Последнюю чашку выпивали все гости по глотку, что означало хабай (дружбу).

Успехи полеводства в XVIII - начале XIX в. позволили воссоздать традиционную основу русской народной кулинарии с привычным соотношением растительных и животных продуктов, хотя доля мясных продуктов в питании населения региона была выше. Продуктовая база расширялась путем акклиматизации новых овощных и садовых культур. Для этого периода характерно преобладание традиционной русской кулинарии, превращение новаций в традиции и появление местных новаций. К середине XIX в. процесс адаптации сис- 
темы питания можно считать в основном завершенным, и в дальнейшем на созданной базе шло ее совершенствование и развитие.

В условиях сибирской зимы представлялось возможным проводить замораживание - термическую обработку и консервацию продуктов с помощью холода («засекание» во льду). Некоторые приемы замораживания русские заимствовали у народов Сибири, а некоторые придумали сами (замораживание пельменей, молока).

Наряду с традиционными продуктами и блюдами, русские охотники и рыбаки употребляли в пищу и воспринятые от коренных народов. При этом инновации можно разделить на две группы. К первой относится снедь и блюда, воспринятые от автохтонных народов и широко употребляющиеся в пищу русским населением. В них не прослеживается специфика питания в условиях промыслов. Видимо, в пищевой набор охотников и рыбаков они попали уже как часть местного варианта русской кухни в целом и их заимствование не связано с промыслами. Примером может служить арушень - творог в виде маленьких лепешек, засушенный в печке, который употреблялся с чаем. Название схоже с бурятским аарул, что может свидетельствовать о заимствовании этого продукта у бурят. А.Д. Батурин называет этот вид снеди в перечне основных продуктов, которые русские брали с собой на охоту в начале XX в.

Бурятская национальная кухня тоже испытала на себе влияние русской. Русское влияние сказалось и на изменении пищевого рациона сибирских аборигенов. Так, в большем количестве стал употребляться хлеб. Буряты научились у русских хлебопечению. Стали употреблять в пищу картофель, овощи, прочно вошли в их рацион некоторые овощные блюда. Однако в силу старых традиций и ограниченности хозяйства бурятское население нечасто употребляло в пищу овощи, картофель, сахар, рыбу, свиное мясо и другие продукты.

B XVIII в. западные буряты начали употреблять в пищу зерновые: ячмень, ярицу, пшеницу, которые составляли уже важную часть пищевого рациона. Для агинских же бурят хлеб еще в конце XIX в. считался лакомством, его подавали к чаю маленькими ломтиками.

Сначала буряты выпекали пресный хлеб, затем научились печь из квашеного теста. Из пресного пекли в золе домашнего очага ржаные и ячменные лепешки, делали лапшу для заправки мясных супов. Из дрожжевого теста на кислом молоке стали выпекать бурятские шаньги.

Изменения в пище начались, когда получило широкое распространение земледелие. В употребление вошли хлебные и мучные изделия: хлеб (хилээмэн), булки (булка), ковриги (хубэрэг, хубэриг), калачи (халааша), лепешки (лепешко), оладьи, блины (бэлины), лапша (лабшаа), крупы (хурпээ). С развитием огородничества в пище появляются картофель (хартаабха), лук (лууг), чеснок, капуста, морковь (морхоог, морхообко), огурцы (гурсэ). В конце XIX XX в. у бурят, перешедших к хлебопашеству, главным в питании становится хлеб, на втором месте - мясная пища, на третьем - молочная.

Основной пищей забайкальских и некоторых предбайкальских бурят были мясо и молочные продукты. Нижнеудинские, окинские и другие буряты, занимавшиеся в основном охотой, употребляли мясо диких животных и зверей. Прибрежные жители Байкала в значительной мере питались рыбой.

K концу XIX - началу XX в. пища бурят стала более разнообразной, расширился ассортимент блюд: вошли в употребление пельмени, котлеты, щи и другие продукты. 
Отражение этнокультурных связей в одежде бурят. Освоение широких пространств с различными природными условиями, многообразие межэтнических связей, появление специфического хозяйственного уклада у отдельных групп русских новоселов не могли не сказаться на их одежде. Изменения выражались в выработке своеобразных черт костюма, в которых новое, возникшее на чужбине (иногда заимствованное), сочеталось со старым, принесенным с собой из родных мест. Изменения происходили довольно медленно: постепенно появлялись региональные особенности.

Русскими были усвоены наиболее рациональные типы одежды местного населения. Русские заимствовали целый набор обуви у коренного населения: как кожаной, так и меховой, в том числе из меха диких животных, прежде не характерной для русской культуры.

Одежда бурят XVIII в. еще не носила следов заимствований. Но уже в начале XIX в. изменения очевидны. Зажиточные буряты начинают переходить к ношению русской одежды. Распространению среди бурят русской одежды и обуви способствовало появление в крае предприятий обрабатывающей промышленности, продукция которых сбывалась и аборигенам. Вместо кожи и шерсти для изготовления одежды все больше применялись сукна и хлопчатобумажные ткани. В Иркутской губернии буряты носили платье, шапки и русские сапоги, в Забайкалье - монгольское платье, сапоги и малахаи. Летом почти все буряты носили одежду из тканей: бумажные и шерстяные ткани покупали у русских, шелковые - у китайцев.

При постепенном переходе бурят к оседлости появились совершенно новые фрормы одежды (зипуны, сарафаны, сапоги), для их изготовления использовался материал домашнего и фрабричного производства. Например, в Предбайкалье стали изготовлять зипун - верхнюю мужскую одежду - из шерстяной вязаной, а затем валяной ткани. Ткань для зипунов отдавали валять русским или, в редких случаях, валяли сами. Способ валяния ткани зипунов отличался от традиционного бурятского, применяемого при изготовлении войлока.

Распространение одежды городского типа - рубах, пиджаков, брюк, сапог и др. - повысило спрос на ткани и изделия фабричного производства. Внедрение и распространение такой одежды были обусловлены частично христианизацией, проводимой миссионерами среди бурят Иркутской губернии, а также желанием богатой прослойки бурят выделиться одеждой среди остальной массы населения и приблизиться к представителям господствующего класса, каковыми были в этом крае русские чиновники и купцы.

Ткани покупали, в основном, на ярмарках, устраиваемых в Иркутске, Киренске, Верхнеудинске, Нерчинске, Баргузине и Кяхте. Приобретала добротные ткани и носила одежду городского типа только зажиточная часть бурятского населения, а остальная довольствовалась одеждой из дешевых тканей дабы, ситца.

Во второй половине XIX в. в Сибири значительно оживляется торговля, обусловленная, прежде всего, развитием капитализма в России. Но постепенно снижается, а в конце XIX в. падает значение кяхтинской торговли. Это было вызвано ограниченным ввозом китайских тканей. Распространение получают русские товары - хлопчатобумажные и льняные ткани, сукно.

Покрой русской одежды, крестьянские ткани, фабричные материалы русского производства, вытеснившие в XIX в. китайские, имели большое значение для развития одежды у народов Сибири. Русские картузы, платки, платья ста- 
ли употребляться оседлыми бурятами, эвенками, тофаларами. Русское же крестьянство использовало в своем обиходе многие части одежды местного населения. Во многих местах, особенно в таежных районах, русские охотники использовали местные типы обуви, одежды или делали свою по их образцу. Тем не менее, традиционный костюм исчез не сразу и не полностью, он подвергся сильной трансформации при сохранении основных характерных черт. Изменения касались, в первую очередь, материала одежды, ее украшений, реже - ее конструктивных особенностей, а также обуви и головных уборов. В регионе имела широкое распространение традиционная одежда русских и бурят, однако ее коснулись изменения, выразившиеся в проникновении русских городских фрорм. К тому же традиционная одежда имела ярко выраженные классовые различия.

В целом уже в конце XVIII - первой половине XIX в. обнаруживаются значительные инновации в области материальной культуры коренных народов региона. Степень этого влияния определялась двумя обстоятельствами: длительностью соседства с русской деревней и распространением земледелия, которое усиливало контакты и влекло за собой переход к оседлому образу жизни, стимулировавшему изменения во многих сторонах материальной культуры.

Религиозный синкретизм. Появление русских в регионе нарушило религиозную однородность населения. Наряду с политеистическими, анимистическими и традиционными шаманскими верованиями коренного населения в крае утверждается православие.

Первые сведения о крещении появляются уже в 30-е гг. XVII в. Крестили взятых в плен бурят и монголов, как мужчин, так и женщин, давая им при крещении русские имена (Сборник 1960: 30, 49, 56, 145, 325). Крещеные мужчины использовались на службе в качестве толмачей (переводчиков), в хозяйственных целях, а женщин выдавали замуж за служилых людей (Сборник 1960: 145). Таким образом, христианизация касалась тех, кто находился в тесных межэтнических контактах и при этом не представлял для государства фрискального интереса.

Религиозный синкретизм у бурят оказался наиболее приемлемым способом постепенного усвоения христианства; медленного, но неуклонного процесса вытеснения язычества; приспособления буддизма к условиям доминирования православной идеологии; мирного сосуществования трех чрезвычайно разных и многомерных стилей мышления и мироощущения - шаманизма, буддизма и христианства. Взаимодействие их было не только внешним, но и внутренним, логически и психологически обусловленным. Русское православие, бурятский шаманизм и бурятский буддизм показали себя открытыми структурами, не лишенными тенденции «обновиться», проявить себя в качестве гибких, универсальных систем. На практике так и получилось - в частности, единичные библейские сюжеты были переработаны и включены в мифологическую систему шаманизма, причем в разных вариантах, а традиции русской народной песенной культуры вплелись в «ёхорные» (хороводные) традиции бурятской молодежи (Михайлова 1999: 97).

Принятие православия означало инкорпорацию в иную этносоциальную общность. Религия в данном случае способствовала ассимиляции, содействовала более быстрому вливанию крещеных аборигенов в русскую среду.

Религиозный синкретизм и усвоение значительного числа элементов из обрядово-бытовой практики православной культуры - так, пожалуй, можно охарак- 
теризовать степень проникновения и усвоения православия в XVII-XX вв. народами Байкальского региона.

В конце XIX в. буряты сумели адаптировать православие, институировать его в свою общественную практику. За сравнительно короткий период - с 1861 по 1917 г. - были созданы институты воспроизводства бурятской православной церкви - училища и семинарии, типографии, издавалась христианская литература на бурятском языке, методические разработки (Михайлова 1999: 59).

В конце XIX - начале XX в. в значительной степени трансформировалась внешняя среда обитания бурят. Переход на оседлость, изменение форм и типов жилищ и поселений, широкое внедрение русской бытовой культуры (а также европейской) не могли не привести к переменам в духовной культуре. Эти и другие изменения в материальной культуре - яркие показатели смены ориентиров в культурном пространстве, выход на новую модель поведения. Выбор религии в качестве позиции (личной или коллективной) не всегда отражал адекватно глубинный смысл явления, он мог определяться и предполагаемыми выгодами или расчетом. В любом случае выбор православия в России выражал стремление индивида или группы приобрести полноценный статус гражданина (Михайлова 1999: 66-67).

1905-1917 гг. явились в истории православия у бурят еще одной важной вехой, показателем степени и глубины усвоения догматов и идей христианства через призму народнических, социал-демократических, национально-освободительных идей, распространившихся не столь широко, но достаточно веско. «Через православную христианизацию - к европеизации образа жизни, культуры и политики» - так можно сформулировать глобальный смысл тех исторических изменений, которые происходили спустя два с половиной столетия после начала христианизации бурят (Михайлова 1999: 150).

Включение в общероссийскую и мировую модели устройства общества, отчетливая тенденция обращения к культурному пространству Запада - процессы, иллюстрирующие выраженное стремление бурятского народа к культурной интеграции, к равноправному диалогу. Русское православие сыграло одну из решающих ролей в исторической судьбе народа, в выходе его на цивилизационную модель развития, волею судьбы, представляющую синтез востока и запада. Процессы инноваций, сопровождавшие культурно-историчес-кое бытие этноса, естественным образом содержали в себе духовный опыт отечественного православия.

Крещение способствовало переходу бурят к оседлости, изменению образа жизни, более тесным контактам с русскими в быту, зарождению семейных связей. Однако христианство не разрушало религиозного миропонимания бурят. Рядом с христианскими богами в мировоззрении местного населения жили тэнгэри, хаты, духи. Культ Николая Угодника был особенно распространен в тех ведомствах, где получило наибольшее развитие земледелие - среди идинских, кудинских, аларских, тункинских и кабанских бурят.

В казачьей церкви в Тунке имелся образ святого Николая, привезенный из русского острожка с Косогола, с бурятским типом: редкой бородой и усами, назад зачесанными волосами и медными украшениями в буддийском стиле с неизменным лотосом. 9 мая этот образ в особенности привлекал бурят, почитавших в нем Цаган-Убукгуна (седого старика), о котором у них существовало много легенд, сходных со сказаниями о святом Николае Чудотворце. 
Интересный случай имел место в Тунке, где находится священная скала Буха-нойон. Ламы на одном из выступов скалы построили буддийскую кумирню, а православные миссионеры в 1861 г. на другом выступе скалы - часовню, посвятив ее святому Парфению. Таким образом, в буддийской кумирне Буханойону молились буддисты, в православной часовне - крещеные буряты, а буряты-шаманисты продолжали устраивать свой традиционный тайлаган.

К христианским датам приурочивались производственно-религиозные обряды шаманистов. Например, накануне Пасхи буряты срезали гривы и хвосты лошадям, обрызгивая вином шаманских богов - покровителей лошадей. Святому Николаю, покровителю земледелия, посвящали тайлаган перед посевом и хлебоуборкой. Так, буряты янгутского рода перед выездом в поле молились по-русски Николаю-бурхану и одновременно совершали обряд по-бурятски, окуривая богородской травой и пихтовой корой лошадь и телегу с семенами, в поле брали с собой буханку хлеба, брызгали водкой. По случаю засухи организовывался крестный ход по засеянным полям, в котором принимали участие и некрещеные буряты. В XVIII в. в быт бурят и эвенков постепенно внедряются русское летосчисление и календарь.

Распространению среди бурят христианского учения способствовали перевод и издание христианской литературы на бурятском языке. Эта литература так или иначе распространялась в бурятских улусах, читалась частью бурят и в устной форме становилась известной многим людям. В сознании шаманистов оставались идеи христианского учения, которые смешивались с шаманскими, а в ряде случаев и с буддийскими. В результате происходило изменение в шаманистском мировоззрении, возникал определенный синкретизм не только в идеологической системе, но и в культовой практике. Следствием влияния христианства явилось двоеверие. Известно немало случаев, когда буряты исповедовали шаманизм и православие или ламаизм и шаманизм.

Принятие христианства бурятами, переселение их в русские деревни или переход на оседлый образ жизни, занятие земледелием, учеба в русских школах и т.д. объективно способствовали развитию культурных связей между русскими и бурятами, взаимодействию и взаимовлиянию, как в материальной, так и в духовной областях жизни. Можно говорить о положительной роли христианства в развитии культуры бурят. Распространение грамоты, побуждение к занятию земледелием, помощь в освоении земледельческих навыков было возможным во многом благодаря распространению христианства среди бурят и эвенков. А вовлечение бурят и эвенков в орбиту экономических, политических и культурных связей Восточной Сибири и всего Российского государства способствовало усилению этих связей с русским народом. Пребывание русского и бурятского народов в едином конфессиональном пространстве существенно способствовало развитию межэтнических связей, сокращению этнокультурной дистанции.

Хозяйственная адаптация русского населения к новой среде обитания должна была повлечь за собой и изменения в религиозных представлениях. Приспособление системы традиционных верований русских к новым условиям протекало при непрерывном взаимодействии с коренными народами региона бурятами, эвенками, что не могло не отразиться на их содержании.

Для того чтобы обезопасить себя от негативного воздействия, необходимо было просто следовать правилам общения с духами-хозяевами: просить разрешения для остановки на отдых, угощать в случае приема пищи на их терри- 
тории. Так как в ведении этих духов обычно находилась небольшая территория, то на ход промысла оказывать влияние они не могли. Свое недовольство они проявляли, мешая спать во время привала.

Имели место и заимствования. Все они были основаны на том, что анимизм - неотъемлемая часть религиозного мировоззрения каждого народа, и духи бурят являются реально существующими и для русских, и наоборот. Речь идет не о полном пантеоне божеств того или иного народа, который отражает реалии его собственной жизни и не будет весь востребован другим народом, а о духах, олицетворяющих лес и водоемы как промысловые угодья, занимающие одинаково важное место в жизни и русских, и бурят, и эвенков. Таким образом, все они стоят перед единым миром сверхъестественного, при этом каждый народ владеет знаниями, позволяющими контактировать только с определенной его частью. Остальное ему незнакомо, но от этого оно приобретает только большее значение.

В силу этого представитель соседнего этноса рассматривается как носитель знания, позволяющего задабривать и просить помощи у незнакомых божеств, при этом часть заимствованной культовой практики применяется и для задабривания собственных духов-хозяев местности. Поэтому русские промысловики, нуждаясь на промысле в нерациональных способах обеспечения удачи, использовали любую информацию о правилах поведения в угодьях, в том числе и полученную от бурят и эвенков. Так, например, если возлияние духамхозяевам спиртного являлось традиционным для русской культуры, то выполнение его путем брызганья по сторонам с кончиков пальцев свидетельствует о заимствовании. Заимствованным считается и запрет проливать кровь рыбы на лед во время подледного лова, в противном случае хозяин будет недоволен, и рыба будет плохо ловиться. Этому русских научили буряты. В язык русских промысловиков прочно вошло слово бурхан в значении дух-хозяин, или место, где совершают ему подношения.

Результатом контакта русских промысловиков с бурятами и эвенками стало почитание духов умерших шаманов. Речь не идет о перенимании всей системы представлений об этой категории духов, существующей у соседних народов. Русское население относилось к шаманам как к людям, обладающим сверхъестественными способностями, и потому считало сакральными их захоронения, а дух шамана воспринимался как дух-хозяин данной местности.

Почитали и почитают русские священные места бурят на дорогах, у рек и на горных перевалах. Они воспринимаются как места, где необходимо совершить символическое подношение духу-хозяину местности - монеты, сигареты, спички, стреляные гильзы и другое - просить хорошей дороги, помощи. Такие представления были широко распространены среди русских Сибири.

В мировоззрении русских сохранялось много суеверий, остатков языческих народных воззрений, которые «оживились», не в последнюю очередь благодаря особенностям жизни и контактам с аборигенами.

Русские в районах тесного проживания с бурятами относились к действительности через призму их мировосприятия. Отношения между людьми находились в одном культурном поле, определялись символическим языком, который был немногословен, конкретен.

Наблюдались фракты вторжения (правда, проявлялся он только внешне) буддизма в религиозные представления русских. 
Бесконфрликтность сосуществования на стыке культур требует, как минимум, уважения религиозных представлений и обычаев соседнего народа, а в лучшем - принятия их. Последнее очень важно при длительном проживании народов на одной территории, поскольку определяет уровень комфортности в сорере межкультурной коммуникации. Все это и присутствовало в складывающемся культурном комплексе Байкальского региона.

Таким образом, синкретизм религиозных воззрений русских и бурят явился источником опыта толерантности, залогом мирного существования и положительного межкультурного взаимодействия.

Зарождение двуязычия. Формы культурной взаимосвязи народов были многообразными. Хозяйственные, административные, торговые и бытовые связи способствовали тому, что русские крестьяне овладевали бурятским, а буряты русским языком. В XVII-XVIII вв. бурятский язык оказывал более сильное влияние на лексику говоров русских старожилов, чем последние на язык бурят. Вопервых, прибывшие на новое место сталкивались с иным растительным и животным миром, и все названия заимствовались у местных жителей. К приходу русских большая часть мест, гор, рек, озер, долин, ключей, речек носила бурятские и эвенкийские названия. Русские восприняли их еще в конце XVII в. Boвторых, общие экономические интересы заставляли русских и бурят общаться на одном из их языков и малочисленное по сравнению с аборигенами пришлое русское население овладевало бурятским языком. При торговле, аренде земли, общих сельскохозяйственных работах, при извозе в основном общались мужчины, поэтому почти все русское мужское население знало бурятский язык, в отличие от женщин и детей, которые либо плохо владели им, либо вовсе не знали его. Первые поселенцы больше занимались скотоводством и учились у бурят этой отрасли хозяйства. Перейдя к земледелию и оседлому образу жизни, буряты приглашали к себе в улусы русских. В период уборки урожая «в наймы» к бурятам шла русская молодежь. Русские крестьяне арендовали земли у бурят под пашни и сенокос. Среди бурят жили русские ремесленники: печники, плотники, столяры, шорники. В русских деревнях было много ясачных, в семьях которых говорили на двух языках - русском и бурятском.

Из русских лексических заимствований в бурятском разговорном языке преобладают обиходно-бытовые и производственно-хозяйственные слова, обозначающие домашнюю обстановку и утварь, продукты питания, одежду и обувь, упряжь и гужевой транспорт, надворные постройки и столярное дело, предметы и явления из области полеводства и огородничества, торговые изделия и финансы.

Наиболее многочисленные заимствования, принятые из бурятского языка в разговорный русский и насчитывающие десятки словарных единиц, также относятся к области хозяйства и быта: термины животноводства, предметы и понятия бытовых и этнографических особенностей.

Достаточно беглого взгляда на фракты взаимных языковых заимствований, чтобы понять, что русские и буряты вступали в контакт на здоровой почве и обогащали друг друга трудовым и жизненным опытом. Если буряты усвоили от русских предметы, понятия и их названия, связанные с полеводством, оседлой обстановкой и товарно-денежными отношениями, то русские переняли у бурят предметы, понятия и их названия, связанные с животноводством и местными сибирскими условиями. 
Бурятское население, перенимая и постепенно усваивая от русских земледельцев приемы и навыки земледельческого хозяйства, приобретало у них не только орудия, но и зерно. Поэтому в бурятском языке можно встретить целый ряд русских слов, обозначающих хлебные и другие растения.

К ранним заимствованиям следует отнести названия некоторых домашних и диких животных и птиц. Русские учились у коренных жителей познавать природу края, в результате чего словарный запас охотников значительно пополнился.

Языковая коммуникация, начиная c XVII в., поддерживалась благодаря билингвизму части населения. Существование в XVII-XVIII вв. среди населения Юго-Восточной Сибири людей (исключая специальный институт толмачества), знающих два и более языков и функционально применяющих их, можно отнести к элементам зарождения новых отношений. Поскольку интегрирующие и дифференцирующие свойства представляют диалектическое единство, то зарождение в XVII в. в полиэтничной сибирской среде двуязычия выступало, с одной стороны, как средство этнокультурного сближения, с другой - консолидационных процессов народностей Сибири.

Межэтнические контакты русских с бурятами осуществлялись и путем биологического смешения. Образовались целые поселения с метисным населением, смешанные браки привели к изменению внешнего облика как русских, так и бурят. В XVII-XVIII вв. русские, вследствие своей малочисленности, испытывали на себе большее влияние бурят, нежели последние на себе. Смешанное население одинаково владело русским и бурятским языками, хотя господствующим был бурятский, восприняло хозяйственные, социально-бытовые черты, традиции и обычаи обоих народов.

Семейно-бытовые отношения. Этнические процессы в таких социальных микроячейках, как семья, отличаются особой активностью в тех случаях, когда эти ячейки возникают в результате брачных союзов между представителями разных этносов. Вместе с тем уже само число таких браков - один из существенных показателей этнического сближения народов (Современные этнические процессы 1977: 460).

Установлению контактов между русскими и бурятами способствовало не только близкое соседство деревень и улусов, но и начавшееся с середины XVII В. смешение населения.

В период интенсивного завоевания бурятских земель к местному населению применялись неизбежные в подобной исторической обстановке методы силового давления. Но уже с середины XVIII в. российское государство переходит от периода завоевания к периоду интеграции местного населения в политическую, экономическую и культурную жизнь страны, обеспечивая ему официальное поощрение и покровительство, создавая условия для его дальнейшего этнокультурного развития.

Первые шаги служилых людей были долгое время немирными, что не могло не оставить некоторую память об этом у местных жителей края. Прошли десятки лет. Буряты постепенно привыкли смотреть на русских как на людей себе подобных, стали сближаться с ними и даже заводить взаимную дружбу. Почти каждый бурят имел в близлежащих русских селах и деревнях дружков, нукуров (нухэр бур. - друг. - О.Б.), точно так же и русские заручались своими дружками, нукурами по улусам. Когда окончательно «водворилось мирное дружелюбное сообщение русских и бурят и, в случаях взаимной вражды и тяжбы из-за хищничества и насилий, в конце концов, закрепилось мировыми записями и т. п. - 
то взаимная социальная симпатия или сожительно-бытовая общительность между русскими и бурятами постепенно все более и более расширялась», писал А.П. Щапов (Щапов 1937: 255).

Первоначально население восточносибирских острогов и городов состояло из одних мужчин. Женщины появились не сразу, и их было мало, поэтому захваченных в плен бурятских женщин крестили и выдавали замуж за служилых людей. В 1683 г. тобольский и сибирский митрополит Павел писал игумену Троицкого Селенгинского монастыря, что, по дошедшим до митрополита сведениям, многие даурские жители жили с некрещеными «иноземками»(бурятками).

В Забайкалье браки русских поселенцев и бурятских женщин поддерживали основанные в этом крае монастыри, стремившиеся таким образом обеспечить оседлость крестьян и тем самым усилить развитие земледелия в пограничных сибирских районах. Большой размах приобрела деятельность ТроицкоСеленгинского монастыря. Ему было предоставлено право селить на своих землях беглых и ссыльных русских и крещеных бурят. Чтобы укрепить основанные деревни, монастырь покупал у бурят «жен и девиц» (выплачивая за них калым) и после крещения выдавал замуж за поселившихся на монастырских землях крестьян. Таким образом возникло метисное население нескольких приходов по Уде и Селенге: Троицкого, Посольского, Куядского и др.

Иногда бурятских женщин похищали или они убегали в русские селения. В том и другом случае монастырское духовенство молча признавало факт хищения и не препятствовало этому, понимая, как важен «женский элемент» в упрочении оседлости и хозяйственности, венчало женщин с их похитителями.

В XVII-XVIII вв. русское население подвергалось более сильному воздействию со стороны бурят вследствие своей малочисленности. Но в первой половине XIX в. в Иркутской губернии буряты все больше подпадали под русское влияние, что нашло отражение в одежде, быте, языке, образе жизни. Тем не менее «и теперь (в 1800-х гг.) русские в отношении усвоения инородческих обычаев и отступлений от национальной культуры стоят почти в том же положении, как и их предки» (Щапов 1937: 86).

Большинство улусных бурят, имевших какие-либо дела с русским населением, также придерживалось их летосчисления. Определение времени по месяцам и дням недели соблюдались в том же порядке. Буддийского летосчисления придерживались только дацаны и ламы, а также буряты «далекой тайги» (Щапов 1937: 153-154).

К положительной стороне русского влияния можно, кроме развития земледелия, прибавить позднейшие: развитие грамотности и более культурных взглядов на саму жизнь.

К отрицательным качествам, которые буряты заимствовали от русских, относят: злоупотребление водкой, картежная игра, сутяжничество, обман, воровство. Нельзя, конечно, отрицать того, что некоторые из этих качеств были у бурят и ранее, но далеко не в таком развитии, как в настоящее время (Щапов 1937: 176). Подражание русским нравам - в том числе дурным - например картежничеству, у многих бурят доходило до страсти. Дела, основанные на одном лишь взаимном доверии, стали сокращаться и постепенно сошли на «нет», появилась жажда к наживе, тунеядство, леность (Щапов 1937: 177). Приверженность молодого бурятского поколения русским нравам и обычаям до того усилилась и распространилась, что вызвала антагонизм и оппозицию со стороны шаманов и стариков (Щапов 1906: 447). 
Кроме соседства или среды, сближению и слиянию местных жителей с русскими способствовало принятие ими русской веры и вступление в русскую службу. Единство распространяемой повсюду господствующей веры и государственного устройства механически соединяло народы в одно целое с русским народом. Крещение давало инородцам право жениться на русских женщинах и производить новое русское поколение (Щапов 1906: 458). В 20-х гг. XIX в. забайкальские буряты составляли четыре казачьих полка, до 600 человек каждый, а тунгусы - отряд в 500 человек. В Иркутске постоянно встречались на улицах казаки-буряты. Такая служба в городах, соседство с русскими казаками и солдатами, общение с русскими не могли не повлиять на характер бурят. Они невольно более или менее усваивали понятия, язык и даже наружный вид русских. Только служба с ее казарменным содержанием и тяжелой дисциплиной часто доводила «вольных инородцев», природных степняков, до деморализации и вымирания (Щапов 1906: 460).

Смешанное население почти одинаково владело русским и бурятским языками и воспринимало хозяйственные и социально-бытовые черты обоих народов. Таким образом, сформировалась особая группа населения (карымы) - посредник общения культур, занимающая промежуточное положение между культурами и являющаяся носителем билингвизма и бикультурализма. Благодаря деятельности группы-посредника знание об иной культуре становилось массовым.

Заключение. Межэтнические контакты, взаимовлияние этносов выражали способ их существования и являлись неотъемлемым свойством их бытия. Это был и есть естественный исторический процесс обмена деятельностью и ее результатами. Межэтническое взаимодействие осуществлялось по разным поводам, в различных сфрерах и находило многогранные фоомы, виды и способы выражения и проявления. Сама структура общества обусловливала существование как группового, так и индивидуально-личностного общения. Реализуясь в групповом и индивидуальном поведении, межэтнический контакт охватывал практически все сферы культуры и быта. В существенной мере изменение этнических свойств под влиянием процессов совершалось на личностном уровне.

Взаимодействие культур русских и бурят в Байкальской Азии является следствием социально обусловленных исторических реалий совместной жизнедеятельности в этноконтактной зоне. В настоящее время данный регион является одним из стабильных районов, в котором проявляется гармоничный полиэтничный характер общества. Это исторически сложившееся поле диалога культур Востока и Запада, уникальный опыт положительного взаимодействия народов, имевших разный опыт освоения региона, исповедовавших разные религии, имевших разный аксиологический багаж.

\section{Әдебиеттер тізімі / Список литературы}

1. Михайлова В.Т. Православие в духовной культуре бурят (30-е гг. XVII в. - 1917 г.). - УланУдэ: Изд-во ВСГТУ, 1999. - 174 с.

2. Павлинская Л.Р. Коренные народы Байкальского региона и русские. Начало этнокультурного взаимодействия // Народы Сибири в составе Государства Российского (очерки этнической истории). - СПб: Европейский Дом, 1999. - 359 с.

3. Сборник документов по истории Бурятии: XVII век / Сост. Г.Н. Румянцев, С.Б. Окунь. - УланУдэ, 1960. - Вып. 1. - 493 с.

4. Современные этнические процессы в СССР. - 2 изд. - М.: Наука, 1977. - 562 с. 
5. Щапов А.П. Историко-этнографическая организация русского народонаселения // Собр. соч. СПб, 1906. - Т. 2. - С. 398-480.

6. Щапов А.П. Эгоистические инстинкты в Ленской народной общине: бурятской улусной, оседло-инородческой и русско-крестьянской // Собр. соч. Доп. том к изд. 1905-1908 гг. - Иркутск, 1937. - C. 224-257.

\section{References}

Mihajlova 1999 - Mihajlova, VT 1999, Pravoslavie v duhovnoj kul'ture burjat (30-e gg. XVII v. - 1917 g.), Izd-vo VSGTU, Ulan-Udje, $174 \mathrm{~s}$. (Mihajlova, VT 1999, Orthodoxy in the spiritual culture of the Buryats (30-ies of XVII century - 1917), Publishing house of ESSTU, Ulan-Udje, 174 p). (in Rus).

Pavlinskaja 1999 - Pavlinskaja, LR 1999, Korennye narody Bajkal'skogo regiona i russkie. Nachalo jetnokul'turnogo vzaimodejstvija, Narody Sibiri v sostave Gosudarstva Rossijskogo (ocherki jetnicheskoj istorii), Evropejskij Dom, Saint Petersburg, 359 s. (Pavlinskaja, LR 1999, The Indigenous peoples of the Baikal region and the Russians. The beginning of ethno-cultural interaction, The peoples of Siberia as part of the Russian State (essays on ethnic history), Evropejskij Dom, Saint Petersburg, 359 p). (in Rus).

Sbornik 1960 - Sbornik dokumentov po istorii Burjatii: XVII vek 1960, Sost. GN Rumjancev, SB Okun', Ulan-Udje, Vyp. 1, 493 s. (Collection of documents on the history of Buryatia: XVII century, Comp. GN Rumjancev, SB Okun', Ulan-Udje, Issue 1, 493 p). (in Rus).

Shhapov 1906 - Shhapov, AP 1906, history and Ethnography of the Russian population, Sobranie sochineniy, T.2, Saint Petersburg, S. 398-480. (Shhapov, AP 1906, Istoriko-jetnograficheskaja organizacija russkogo narodonaselenija, Collected works, Vol.2, Saint Petersburg, P. 398-480). (in Rus).

Shhapov 1937 - Shhapov, AP 1937, Jegoisticheskie instinkty v Lenskoj narodnoj obshhine: burjatskoj ulusnoj, osedlo-inorodcheskoj i russko-krest'janskoj, Sobranie sochineniy: Dop. tom k izd. 19051908 gg, Irkutsk, S. 224-257. (Shhapov, AP 1937, Egoistic instincts Lena folk community: Buryat ulus, settled-native and Russian-peasant, Collected works: supplementary volume to the edition of 1905-1908 gg, Irkutsk, P. 224-257). (in Rus).

Sovremennye jetnicheskie processy 1977 - Sovremennye jetnicheskie processy v SSSR, Nauka, Moscow, 562 s. (Contemporary ethnic processes in the USSR, Nauka, Moscow, 562 p). (in Rus). 